\title{
A Multidisciplinary Analysis of Non-Literary Latin Texts from Roman Britain
}

Francesca Cotugno

University of Nottingham / University of Oxford

\begin{abstract}
The present paper is focussed on the major corpora of non-literary documents written on tablets in Roman Britain. This encompasses the stylus tablets from Londinium-Bloomberg, the ink-written tablets from Carlisle and Vindolanda, and the curse tablets incised on lead. The main purpose of this analysis is to show from a quantitative perspective how these different corpora diverge from each other not only in respect of the writing material but also according to the presence or absence of specific linguistic features: gemination, degemination, vowel syncope, and presence or absence of initial $h$-.
\end{abstract}

\section{Keywords}

historical sociolinguistics; Roman Britain; non-literary documents 


\section{Introduction}

The scholarly interest in Roman Britain encompasses different fields such as the sociohistorical and linguistic (Adams 2007: pp. 581-582; Mullen 2016: pp. 584-585). There is a historical coincidence between Roman rule and the first documents written on tablets - in this case stylus tablets - from the area of Londinium-Bloomberg, as these texts represent the oldest documentation available on writing tablets in Roman Britain (Tomlin 2016: p. xiii).

For the present analysis the non-literary sources considered are presented in Table 1.

Table 1: Synopsis of the non-literary corpora written on tablet from Roman Britain

\begin{tabular}{|c|c|c|}
\hline Corpus & Date & n. of tablets \\
\hline Londinium-Bloomberg $^{1}$ & $50-80 \mathrm{CE}$ & 405 \\
\hline Carlisle $^{2}$ & $79-105 \mathrm{CE}$ & 77 \\
\hline Vindolanda $^{3}$ & $85-205 \mathrm{CE}$ & 772 \\
\hline Curse tablets $^{4}$ & $2^{\text {nd }}-4^{\text {th }}$ century CE & 200 \\
\hline
\end{tabular}

The Londinium-Bloomberg stylus tablets date to between 50 and 80 CE. Evidence from the texts shows a varied provenance of the writers with the Vangiones, the Nervi, the Lingones and also people coming from Noricum mentioned (Tomlin 2016: pp. 51-54). These tablets can be described as generally formal documents since the whole corpus consists mostly of official correspondence (i.e., deeds and contracts). Due to the level of formality of these documents, the non-classical forms available in this corpus are few and they are also not particularly relevant as long as they occur only once. Thus, it is not possible to set a consistent comparison between Classical and non-classical occurrences.

The other two corpora, Carlisle and Vindolanda, belonged to the military forts from the area of Hadrian's wall. The fort of Carlisle, once known as Luguualium, was garrisoned by the auxiliarii from the Ala Gallorum Sebosiana (Tomlin 1998: pp. 31, 36),

My gratitude goes to Dr Béla Adamik (HAS Momentum - ELTE University) and also to Dr Daniela Urbanová (Masarikova University) which encouraged me to pursue my work further with useful comments and advice. Special thanks also goes to Dr. Alex Mullen for her proofreading and for her comments. This paper was presented at the Second International Workshop on Computational Latin Dialectology, Budapest, 30-31 March, 2017. This paper is also part of the LatinNow project (latinnow.eu) whose principal investigator is Dr Alex Mullen. LatinNow aims to situate the phenomena of Latinization, literacy, bi- and multilingualism within broader social developments. The project is hosted by the University of Nottingham and based at the Centre for the Study of Ancient Documents (CSAD), University of Oxford. LatinNow receives funding from the European Research Council (ERC) under the European Union's Horizon 2020 research and innovation programme (grant agreement No 715626).

1 Based on the very recent publication, Tomlin (2016).

2 Tomlin (1998) is the current edition of the Carlisle writing tablets.

3 Composed of the following editions: Bowman \& Thomas (1994; 2003) and Bowman, Thomas \& Tomlin (2010; 2011).

4 Composed mainly of Tomlin (1988; 1993) concerning the main sites of Bath and Uley and the other minor documents collected through the previous work of Amina Kropp (2008), adding new materials coming from the archaeological writing report (Gurney 1986) and publications in the journal Britannia after 2008 (Tomlin 2009; 2010; 2011; 2012; 2013; 2014; 2015; 2016). 
whereas Vindolanda was garrisoned by Batavians ${ }^{5}$ and Tungrians in the periods in which the tablets were written (Bowman \& Thomas 1994: pp. 22-24). It should be noted that the documents from Carlisle represent the first record of military correspondence written on tablets from Roman Britain (Tomlin 1998: p. 34). Also, in this corpus, as well as in the others, style ${ }^{6}$ played a relevant role as the non-classical features collected were not so frequent - at least not as frequent as in the Vindolanda corpus - and they may be interpreted as isolated minor misspellings (e.g. karrissime Tab. Luguv. 40) or as nonclassical forms pertaining to a single tablet (i.e. the 16 cases of ordei from Tab. Luguv. 1).

Conversely, concerning Vindolanda, the varied records from this corpus are not always easy to interpret. This is the richest set of non-literary records from Roman Britain and the discovery of these wafer-thin tablets in 1973 certainly had an impact on the story of the Roman army and - more importantly for our purposes - on the use of writing, writing material, and Latin by these soldiers (Blackshaw 1974: p. 244). It is noticeable that some of the tablets give clues of a high standard of literacy, maybe due also to the presence of professional scribes: these are documents of praefectorial correspondence, or other formal records such as leave requests, recommendations and memoranda. On the contrary, there are other documents which may be intended as less formal and are more prone to showing non-classical elements. These documents offer a glimpse of the command of spoken Latin of the writers from Vindolanda: these are the personal correspondence from people different from the praefects, accounts and lists and other kind of reports (e.g. Tab. Vindol. 181, 343, 344, 595, ex multis). For the sake of clarity, the Vindolanda documents may be divided into two main typologies: formal correspondence (composed by letters of recommendation, request of leave, memoranda, reports), and personal correspondence, including those written by women, which can be considered as non-formal.

The most recent corpus is composed by the curse tablets (which can be broadly dated between $2^{\text {nd }}-4^{\text {th }}$ century $\mathrm{CE}$ ), which have been largely found in different areas in the southern-western part of this province, mainly at the temples of Bath and Uley (Tomlin 1988; 1993). The writers of these tablets belonged presumably to the local population with a strong influence of Celtic languages (Mullen 2007a: p. 32; Adams 2016: pp. 422, 427; Cotugno, in press). In summary, there seems to be three corpora presumably largely written by people coming from outside Britain and one composed by the texts written by people from Britain (Tomlin 1988: pp. 97-98).

5 The $9^{\text {th }}$ cohors of Batavians is the auxiliary cohort which left behind the higher number of writing-tablets at Vindolanda. It was stationed at Vindolanda in the late 80 s to early $90 \mathrm{~s}$ CE. Like all the auxiliary units of the first centuries of this era, it was made up of non-citizen recruits, and came from the region of the Upper Rhine, between the Rhine and the Waal (Battaglia 2013: p. 53).

6 In the sense of the text type involved, which will be briefly considered in $\$ 2.1$, and the level of formality of the different documents taken into consideration. 


\section{Different types of variation}

The key aim of the analysis of these documents is to show the distribution of the nonclassical occurrences of non-literary Latin attested in Roman Britain according to the areal and, when possible, the diachronic axes of linguistic variation. The diffusion of a certain phonological phenomenon and the number of its attestation in a specific area, text type or social strata can help in disambiguating if we are dealing with a mere slip of the pen, an idiolectal form pertaining to a single writer or, conversely, with a well-spread non-classical form among a certain community of writers. As a matter of fact, these different corpora show how Roman Britain had, according to the different community of writers, a different profile for what concerns at least the phonological variation that can be supposedly be detected in written records. Owing to this, it would be more correct to talk about micro-histories of Latinization instead of the former labels of Latin in Britain and Latin of Britain (Cotugno, in press). Variation among these different communities of writers will be highlighted through the analysis of a few specific and emblematic case studies: vocalic syncope, consonantal gemination and degemination, and $h$ - insertion in initial position.

\subsection{Vocalic syncope}

With reference to vocalic syncope, it is possible to notice that the distribution of this phenomenon differs both geographically and chronologically (see Adamik 2016: pp. 20-21). However, it is relevant to notice that the tablets from Londinium-Bloomberg and Carlisle do not present cases of vocalic syncope (see Table 2). As mentioned above (see $\S$ 1), the Londinium and Carlisle corpora belong to a consistently higher level of formality. Conversely, the real comparison is between the Vindolanda corpus and the curse tablets (see Figure 2).

Table 2: Vocalic syncope in the non-literary corpora from Roman Britain

\begin{tabular}{|c|c|c|c|}
\hline Corpus & Pre-tonic syncope & Post-tonic syncope & Total \\
\hline Londinium-Bloomberg & 0 & 0 & 0 \\
\hline Carlisle & 0 & 0 & 0 \\
\hline Vindolanda & $8(20 \%)$ & $25(82 \%)$ & 33 \\
\hline Curse Tablets & 0 & $3(100 \%)$ & 0 \\
\hline
\end{tabular}

Compared to the other corpora (see Table 2), Vindolanda offers a more consistent selection of vocalic syncope. The evidence collected from this corpus consists of 33 instances distributed mostly in post-tonic position:

-25 cases in post-tonic position (i.e. $82 \%$ )

- 8 cases in pre-tonic position (i.e. $20 \%$ )

Moreover, it should be added that these 33 cases from Vindolanda are distributed among the different text types available for this unique corpus of writing-tablets (see Table 3): 
Table 3: Vocalic syncope in the Vindolanda corpus

\begin{tabular}{|c|c|}
\hline Text type & n. of tablets showing vocalic syncope \\
\hline Account & $16(49 \%)$ \\
\hline Personal correspondence $(\mathrm{M})^{7}$ & $14(42 \%)$ \\
\hline Personal correspondence $(\mathrm{F})^{8}$ & $0(0 \%)$ \\
\hline Military report & $0(0 \%)$ \\
\hline Memorandum & $1(3 \%)$ \\
\hline Request of leave & $1(3 \%)$ \\
\hline Letter of recommendation & $0(0 \%)$ \\
\hline Miscellaneous & $1(3 \%)$ \\
\hline Total $^{8}$ & $33(100 \%)$ \\
\hline
\end{tabular}

As shown in Table 3, the large majority of instances occurs in accounts (16 cases, 49\%) and personal correspondence written by men (14 cases, $42 \%$ ) whereas the phenomenon is totally absent from female correspondence. ${ }^{10}$ In documents characterised by a higher degree of formality this phenomenon is sporadic, except for one case in a request for leave (Tab. Vindol. 170, 3\%), one memorandum (Tab. Vindol. 593, 3\%) and a miscellaneous text (Tab. Vindol. 712, 3\%). In the majority of occurrences recorded, the vowel involved is $/ \mathrm{u} /$, mostly in post-tonic position. Vowel syncope in pre-tonic position involves $/ \mathrm{u} /$ in $62 \%$ of cases (5), whereas the remaining $37 \%$ involve $/ \mathrm{e} /$ (3 cases). A different situation is evident for the post-tonic occurrences, as there are only few cases involving $/ \mathrm{i} /(8 \%, 2$ cases $), / \mathrm{o} /(8 \%, 2$ cases $)$, whereas the majority of occurrences (i.e. the $84 \%$ of cases) involves $/ \mathrm{u} /$.

Conversely, evidence from the curse tablets is scanty compared to the Vindolanda corpus. Curse tablet writers came from a different milieu, which was generally less educated, were from a later period (from the $2^{\text {nd }}$ to $4^{\text {th }}$ century CE), and are possibly representative of the writing production of the local population, instead of the auxiliaries from the Continent. The onomastics and a couple of tablets provide evidence of the insular provenance of the writers (in particular Tab. Sul. 14 and 18, see Mullen 2007b: p. 55).

In the curse tablets, all the 3 cases of vowel syncope occur in post-tonic position. ${ }^{11}$ The words involved in this phenomenon pertain to everyday language (domna Caerleon), the onomastics (Mintla Rufus Uley 55) and to the verbal class with the form perdre (Tab. Sul. 103). However, among the curse tablets analysed the word PAVLATORIAM for

$7 \quad$ I.e. Personal correspondence written by men.

8 I.e. Personal correspondence written by women. In total, the letter ascribable to women, are only 12. However, it is not possible to clarify whether these documents were written entirely by women or with the help of scribes.

9 The category of miscellaneous documents has been adopted in order to include those documents whose text type is not identifiable.

10 It has to be added that - compared to the rest of the Vindolanda corpus - the overall number of documents ascribable to women is very low.

11 As expected in Latin once the Penultimate Law was established, prescribing that the stressed syllable cannot be more than three syllables from the end of the word (Baldi 1999: p. 268). 
pabulatoriam (Ratcliffe-on-Soar, Mullen 2013: p. 268) deserves special consideration. It cannot be taken into account as a case of syncope as it should have been happen between a probably bilabial fricative $[\beta]$ and a liquid and this is not possible since syncope happens between stops and liquids. Interpreting PAVLATORIAM as an orthographical simplication, provided a change of $[\mathrm{b}]$ to $[\beta]$, appears as more fitting. There are also cases of pseudo-syncope, like Dcillinae for Docillinae (Silchester), which must be excluded from this analysis as this kind of syncope does not occur in the first syllable, which has a secondary stress. As a matter of fact, this form can be labelled as an omission of $<_{0}>$ probably because of a lapsus calami.

Compared to the evidence collected from the Vindolanda corpus, the relative absence of this phenomenon may be seen as relevant. Moreover, the phenomenon shows also a scattered diffusion concerning the targeted vowels, involving $[\mathrm{i}],[\mathrm{u}]$, and $[\mathrm{e}]$ in the posttonic position.

\subsection{Consonantal gemination and degemination}

Gemination and degemination represent a fairly controversial topic, as it is difficult to disambiguate the cases in which the geminated and degeminated forms actually reflect the social class or the different provenance of the writers, whose mother tongue was presumably Celtic or Germanic. Moreover, regarding the curse tablets, the magical context provides a possible incentive for deliberate misspellings (Tomlin 1988: p. 174). ${ }^{12}$ Nonetheless, the comparison between the cases of gemination and degemination might help to investigate whether the documents with a prevalence of geminated not archaising forms are ascribable to writers of a Germanic milieu. Conversely, the degeminated forms have been linked to Celtic languages in contexts outside Britain, for example in texts such as the pottery records of La Graufesenque (Aveyron, France) (Marichal 1988)

Table 4: Gemination and Degemination in non-literary corpora from Roman Britain

\begin{tabular}{|c|c|c|}
\hline Corpus & Gemination & Degemination \\
\hline Londinium-Bloomberg & $5(0,7 \%)$ & $2(0,2 \%)$ \\
\hline Carlisle & $1(0,1 \%)$ & $0(0 \%)$ \\
\hline Vindolanda & $35(0,3 \%)$ & $14(0,2 \%)$ \\
\hline Curse Tablets & $19(0,5 \%)$ & $27(1 \%)$ \\
\hline
\end{tabular}

Starting from the older corpus, in the Londinium-Bloomberg there are very few cases for both of these phenomena (see Table 4 ) as it shows only 5 cases of gemination involving 3 word-types (ussura Tab. Lond. 55, 56; promissit Tab. Lond. 55, 56; occassionem Tab. Vindol. 29). The consonant involved is always [s] and for the very same reason, the geminated [s:] may be caused not by phonological processes but by stylistic choices in the financial style, since it generally pursues a taste for the old-fashioned in spelling.

12 Concerning the curse tablets, many of the linguistic or graphemic features available may have been added in in order to add additional persuasive power (Faraone \& Kropp 2010: pp. 396-397). 
Conversely, one case involves degemination of the voiceless dental [ $\mathrm{t}$ ] (Tab. Lond. 31 Aticus) and the other one the sibilant [s] (faenerase, Tab. Lond. 30). Similarly, the collected data show that the Carlisle texts account for just one case (which is karrissime Tab. Lug. 40). This is not surprising because Carlisle contains the highest number of formal texts (more than 80\%). From this corpus, no cases of consonantal degemination have been collected. The scarcity of cases of consonantal gemination together with the absence of consonantal degemination may be seen as another clue as to the role of stylistic variation in the presence of more or less cases of non-classical forms.

In the Vindolanda corpus, the situation is different as the text types involve nonformal personal correspondence and accounts (Cotugno \& Marotta 2017). Moreover, in this corpus the voiceless alveolar fricative has the highest occurrence rate, with 〈ss $\rangle$ showing 28 cases out of 37 (i.e. 73\%), the other cases, namely <cc, dd, ff, ll, mm, rr, tt>, occur only once each (except $\langle\mathrm{ff}\rangle$, which occurs twice in reffecti Tab. Vindol. 691 and offellam Tab. Vindol. 207). Some of these cases can be considered as misspellings, since another geminate consonant occurs in the preceding syllable (e.g. offellam Tab. Vindol. 207, occassionem Tab. Vindol. 225).

Compared to Vindolanda, curse tablets show an inverse trend for gemination, as there are 18 occurrences whereas for degemination, the number of cases is higher with 29 attested forms. In the case of curse tablets, there is a no real tendency towards the degemination of voiced versus voiceless consonants, as 16 cases pertain to voiceless and 13 to voiced consonantal group (Cotugno, in press). Nonetheless, [1] appears as the most degeminated consonant in the whole corpus and its instances cover recurring words such as anillus (Tab. Sul. 97; Lydney Park) or ancilla (Brandon and Southern Britain curse tablets) scoring a total of 13 cases. These forms are also frequent, but more importantly, the only form attested is non-classical and there are no evidences of its classical form.

\section{3 $\mathrm{H}$ - insertion in initial position}

The last phenomenon to be considered is the $<\mathrm{h}>$ insertion in initial position, resulting in the presence of an unexpected and un-etymological $h$-. In reference to the use of $h$ - in this position, it should be noted that the loss of the aspirated sound started in sub-elite varieties and gave rise to a period of transition at an early date, i.e. the $3^{\text {rd }}$ century BCE (Allen 1965: pp. 53-54). During this period hypercorrect forms were abundant to compensate for this lack of pronunciation (Sturtevant 1947: p. 56; Leumann 1977: p. 144). The spread of the use of $h$, especially in initial position, was thought to be a social marker (Clackson \& Horrocks 2007: pp. 240-241). Taking into account this information, the graphemic hypercorrection may betray the writer's lack of competence as he did not know how the Classical word was supposed to be written. Such a loss of control can be explained in different ways: it can be taken as a sign that the writer had not had a fullyfledged education, or that there is a second language which was influencing his Latin, as the $h$-may have a phonetic value. In the sources examined, only the Vindolanda corpus offers evidences of $h$-insertion in initial position, as here 11 cases have been collected. 
In the other corpora taken into consideration there is no evidence of this phenomenon. This could be linked to the presence of Batavian and Tungrian writers, who are not obviously present in the other corpora.

In the Vindolanda corpus, the targeted words are personal names - mainly of Germanic origin - and words of everyday language (Huennius, Tab. Vindol. 184; Hrindens Tab. Vindol. 885; hostrea Tab. Vindol. 622, halica). On the one hand, if the words from everyday language are debated as there are different spellings available (e.g. halica vs. alica, cf. Tab. Vindol. 193, 586 and Tab. Vindol. 233, also have, Tab.Vindol. 291), ${ }^{13}$ this does not apply to the encountered personal names. On the other, the non-classical spelling of these proper names (i.e. Huennius, Hueteris) may betray the absence of the Classical norm in this sense which the writer tried to overcome by adopting a phonological spelling. In this normative void, the spoken language presumably makes an appearance through insertion of an $\langle\mathrm{h}\rangle$ which was no longer used in Latin, according to the contemporary evidence.

Table 5: $\mathrm{H}$ - insertion and deletion in non-literary documents from Roman Britain

\begin{tabular}{|c|c|c|}
\hline Corpora & $H$ - Insertion & $H$-Deletion \\
\hline Londinium-Bloomberg & 0 & $1(0,1 \%)^{14}$ \\
\hline Carlisle & 0 & $16(3 \%)$ \\
\hline Vindolanda & $11(0,1 \%)$ & $6(>0,1 \%)$ \\
\hline Curse Tablet & 0 & $2(0,3 \%)$ \\
\hline
\end{tabular}

Moreover, the opposite phenomenon, i.e. the deletion of the $\langle\mathrm{h}\rangle$ in initial position, is more generalised and available in all the analysed corpora (see Table 5).

It should finally be emphasised that the relatively high outcome from Carlisle is caused by one single tablet (i.e. Tab. Lug. 1) in which the very same word hordei, is misspelled as ordei (Tomlin 1998: pp. 42-43).

\section{Conclusions}

These case studies, namely vocalic syncope, gemination, degemination, $h$-insertion and deletion in initial position, were selected according to their specific relevance in the different corpora taken into consideration although they did not occur with the same frequency. As a matter fact, those corpora whose documents are of a more formal nature, i.e. Londinium-Bloomberg and Carlisle, showed a different scenario when compared to the Vindolanda tablets and the curse tablets. Albeit all written documents can be consid-

13 Have can possibly be considered as a normative and classical variant, for this reason, the word have must be treated separately as potentially correct variant (see Donat. gramm. IV 383, 16 Prisc. gramm. II 450, 16 Cledon. gramm. V 59, 23 Consent. gramm. V 370, 12 Phocas gramm. V 436, 14 Gramm. suppl. 53, 8 et p. xxi but also Treb. Claud. 18, 2; Lampr. Alex. 7, 6 Cod. Theod. gest. in sen. p. 86).

14 It should be mentioned that in Tab. Lond. 27 there is a cirographum instead of chirographum. But it is the only altered aspirated consonant involved in this corpus. 
ered formal from a general perspective, as the intrinsic nature of a written document is, in itself, formal, some documents are more formal than others. In general, it is noticeable that the Vindolanda corpus and the curse tablets arise as the two corpora with the highest number of features available. However, the numbers of collected features are not dramatically high: it was possible to collect consistent numbers in only few occasions and more importantly, they are low if compared with the overall number of words for each corpus (see Table 6):

Table 6: Synopsis of the cases studies analysed

\begin{tabular}{|c|c|c|c|c|c|c|}
\hline Corpora & n. words & Syncope & Gemination & Degemination & $H$-Insertion & $H$-Deletion \\
\hline Londinium-B. & 745 & $0(0 \%)$ & $5(0,7 \%)$ & $2(0,2 \%)$ & $0(0 \%)$ & $1(0,1 \%)$ \\
\hline Carlisle & 615 & $0(0 \%)$ & $1(0,1 \%)$ & $0(0 \%)$ & $0(0 \%)$ & $16(3 \%)$ \\
\hline Vindolanda & 9154 & $33(0,4 \%)$ & $35(0,3 \%)$ & $14(0,2 \%)$ & $11(0,1 \%)$ & $6(>0,1 \%)$ \\
\hline Curse tablets & 3236 & $3(0,1 \%)$ & $19(0,5 \%)$ & $27(1 \%)$ & $0(0 \%)$ & $0(0 \%)$ \\
\hline
\end{tabular}

Despite the different number of words for each corpus, the difference in the percentage of occurrences for each feature taken into consideration is not significant (see Table 6). However, the general percentage should not be taken as particularly significant anyway, as comparing the different occurrences of the phenomenon with the overall number of words simply gives a rough idea of frequency of occurrence. A full comparison of the rate of non-Classical for Classical spellings can only be accurately achieved by comparing the contexts in which a specific non-Classical feature occurs against all the times in which it could have occurred but did not. But given that it is difficult to identify all the circumstances for the latter in these large corpora, the rate of occurrence of these features has been given against the total number of words, and this at least gives a general sense of frequency that can be easily compared across the corpora. As a matter of fact, compared with the overall number of words for each corpus, any of the case studies considered is not particularly relevant. However, it is important instead to consider each tablet as an independent element from the rest of the corpus, as it can add important information about the Latin in use in it and the specific writing performance. Internal reference can be adopted through the different non-classical spelling in order to check whether there were other writers who also adopted a non-classical form or, conversely, adhered to the Classical spelling. Nonetheless, a large-scale analysis allows for the identification of two main axes of stylistic variation: formal and non-formal. The corpora characterised by formal documents were significantly less affected by non-classical phenomena, whereas in the case of Vindolanda non-classical spellings have been attested more times and were easier to find in less formal documents. The letters in which the presence of trained scribes and the direct hand of the prefects can be recognised usually remain free from the presence of non-classical features.

A relevant role was also played by areal variation. As a matter of fact, the two corpora of Vindolanda and curse tablets arise as the most indicative for what concerns nonclassical forms. In this sense, it is possible to infer an areal variation as in the North we can detect the presence of records written by people coming from outside Britain and 
pertaining to a military milieu. Conversely, in the South, there is multiple evidence of the locals' and civilian use of Latin through a practice imported from the Continent (the use of curse-tablets) adapted to the local customs (Cotugno, in press). However, this type of variation is only apparent, since the writers from the North were in fact from the Continent - as they were Batavians and Tungrians - whereas the curse tablets can supposedly be ascribed to the local population. Instead of assessing a sharp-edged areal distinction it would be more convenient to emphasise the fact that there is another kind of diversity. The written tablets collected from the North represent an important facet of the military records from Roman Britain, whereas the curse tablets (and to a certain extent also the Londinium-Bloomberg tablets) belong to the production of the civilian society.

Besides these two main blocks accounting for areal variation, it should be added that identifying other sociolinguistic variants (e.g., the diastratic variation) would be useful but it is not a simple task. Whilst these records - whether official or non-official - contain different contextual information regarding their possible writers, it is debatable whether there is any certainty about the correspondence between the name of the sender written on the back of the tablet and the hands which wrote the relative texts (Halla-Aho 2009: p. 61). This is especially true for what concerns the Vindolanda writing tablets, in which sometimes many different hands are recognisable (Bowman \& Thomas 1994). In this way, there is no certainty about the authorship of the non-classical form and the only distinction that can be made, even if without sharp borders, is a distinction between praefectorial correspondence and the rest of the records. In the first category, non-classical forms are fewer and isolated whoever the author, whether Flavius Cerialis, prefect of the $9^{\text {th }}$ cohors of Batavians or one of his scribes.

The case studies chosen for this paper are the most emblematic of the linguistic situation from Roman Britain. Moreover, due to the different origins of the writers, geographical varieties may have sometimes been reflected in their written production. This is what has been called micro-histories of Latinization, as such differences are not apparent as the Latin language had a levelling force (Cotugno, in press). Each of the corpora taken into account may be seen as a different tile of the social and ethnic mosaic composing the Romano-British framework.

In the following figure the results of the case studies are presented (see Figure 1):

It is important to highlight that - due to the complex nature of the Romano-British cultural and ethnic framework starting from the first two centuries of the occupation - a straightforward comparison between the corpora taken into consideration is not advisable, as the variants are too intertwined and many of them are still unknown. Moreover, the corpora considered are spread over several centuries (see Table 1). However, it is noteworthy to point out that while the older corpora of Londinium-Bloomberg and Carlisle seem to maintain a higher degree of correctness, such adherence to the Classical norm is merely apparent because it is not necessarily caused by their chronological collocation, but rather by other factors such as stylistic variation, the different provenance of the writers, and their cultural milieu.

Each corpus represents a relevant element in the complex scenario of the Romano British society, offering relevant information concerning the change of Latin itself 


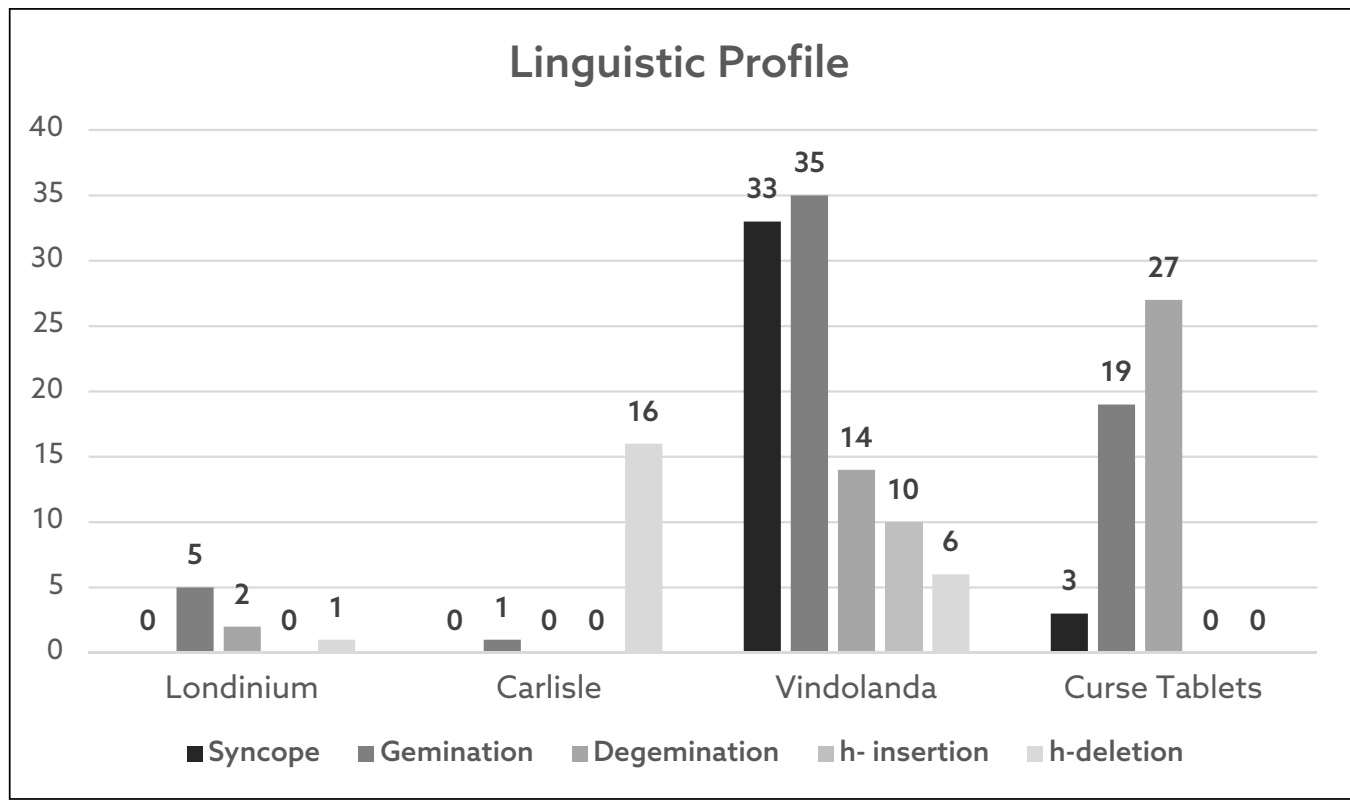

Figure 1: Different distributions according to the non-classical forms found in the different corpora written on tablets

through linguistic contact and - more importantly - concerning the different identities that the different linguistic varieties may express through non-classical spellings. The analysis conducted on these data, taking into consideration the different outcomes available, is a stepping stone into an in-depth research which will hopefully contribute to the scholarly debate by employing socio-linguistic evidence to test theories regarding the composition of the different communities in Roman Britain and the north-western provinces more broadly.

\section{Bibliography}

Adams, J. N. (2007). The Regional Diversification of Latin, 200 BC-AD 600. Cambridge: Cambridge University Press.

Adams, J. N. (2016). An Anthology of Informal Latin, 200 BC-AD 900. Cambridge: Cambridge University Press.

Adamik, B. (2016). The Frequency of Syncope in the Latin of the Empire: A Statistical and Dialectological Study Based on the Analysis of Inscriptions. In P. Pocetti (Ed.), XVII Colloquium of Latin Linguistics, May 20th - May 25th 2013 (pp. 3-21). Berlin - Boston: De Gruyter.

Allen, W. S. (1965). Vox Latina: A Guide to the Pronunciation of Classical Latin. Cambridge: Cambridge University Press.

Baldi, P. (1999). Foundations of Latin. Berlin - New York: Mouton-De Gruyter. 
Battaglia, M. (2013). I Germani. Genesi di una cultura europea. Roma: Carocci.

Blackshaw, S. M. (1974). The Conservation of the Wooden Writing-Tablets from Vindolanda Roman Fort, Northumberland. Studies in Conservation, 19(4), 244-246.

Bowman, A. K., \& Thomas, J. D. (1983). Vindolanda: The Latin Writing Tablets (Britannia Monographs, 4). London: London Society for the Promotion of Roman Studies.

Bowman, A. K., \& Thomas, J. D. (1994). The Vindolanda Writing Tablets (Tabulae Vindolandenses, II). London: British Museum Press.

Bowman, A. K., \& Thomas, J. D. (2003). The Vindolanda Writing Tablets (Tabulae Vindolandenses, III). London: British Museum Press.

Bowman A. K., Thomas, J. D., \& Tomlin, R. S. O. (2010). The Vindolanda Writing-Tablets (Tabulae Vindolandenses, IV, part 1). Britannia, 41, 187-224.

Bowman, A. K., Thomas, J. D. \& Tomlin, R. S. O. (2011). The Vindolanda Writing-Tablets (Tabulae Vindolandenses, IV, part 2). Britannia, 42, 113-144.

Clackson, J., \& G. Horrocks (2007). The Blackwell History of the Latin Language. Malden: WileyBlackwell.

Cotugno, F. (in press). Voci di Britannia. In L. Costamagna, A. Marcaccio, S. Scaglione, \& B. Turchetta (Eds.), Mutamento linguistico e biodiversità. Atti del XLI Convegno annuale della Società Italiana di Glottologia. Roma: Editore Il Calamo.

Cotugno, F., \& Marotta, G. (2017). Geminated Consonants in Vindolanda's Tablets. Empirical Data \& Sociolinguistic Remarks. In P. Molinelli (Ed.), Linguistic Representation of Identity (pp. 269-288). Berlin: Mouton de Gruyter.

Faraone, C. A., \& Kropp, A. (2010). Inversion, Adversion \& Perversion as Strategies in Latin CurseTablets. In R. Gordon, \& F. M. Simón (Eds.), Magical Practice in the Latin West (pp. 381-398). Leiden: Brill.

Gurney, D. (1986). Settlement, Religion \& Industry on the Fen-edge; Three Romano British Sites in Norfolk. East Anglian Archaeology Report, 31, 1-193.

Kropp, A. (2008). Defixiones: Ein aktuelles Corpus lateinischer Fluchtafeln. Speyer: KartoffeldruckVerlag.

Halla-Aho, H. (2009). The Non-Literary Latin Letters. A Study of Their Syntax E゚ Pragmatics. Helsinki: Societas Scientiarum Fennica.

Leumann, M. (1977). Lateinische Laut- und Formenlehre. München: Bech.

Marichal, R. (1988). Les graffites de La Graufesenque (Gallia, Suppl. 47). Paris: Editions du Centre national de la recherche scientifique.

Mullen, A. (2007a). Linguistic Evidence for 'Romanization': Continuity \& Change in RomanoBritish Onomastics. A Study of the Epigraphic Record with Particular Reference to Bath. Britannia, 38, 35-61.

Mullen, A. (2007b). Evidence for Written Celtic from Roman Britain: a Linguistic Analysis of Tabellae Sulis 14 \& 18. Studia Celtica, 41, 29-43.

Mullen, A. (2013). New Thoughts on British Latin: a Curse Tablet from Red Hill, Ratcliffe-on-Soar (Nottinghamshire). Zeitschrift für Papyrologie und Epigraphik, 187, 266-272.

Mullen, A. (2016). Sociolinguistics. In M. Millett, A. Moore, \& L. Revell (Eds.), The Oxford Handbook to Roman Britain. Oxford: Oxford University Press.

Sturtevant, E. (1947). An Introduction to Linguistic Science. New Haven: Yale University Press. 
Tomlin, R. S. O. (1988). Tabellae Sulis: Roman Inscribed Tablets on Tin E Lead from the Sacred Spring of Bath. In B. Cunliffe (Ed.), The Temple of Sulis Minerva at Bath, 2: The Finds from the Sacred Spring (Monograph; Oxford University Committee for Acheology, 16; pp. 59-269). Oxford: University Committee for Archaeology.

Tomlin, R. S. O. (1993). The Inscribed Lead Tablets. In A. Woodward, \& P. Leach (Eds.), The Uley Shrines: Excavation of a Ritual Complex on West Hill, Uley, Gloucestershire, 1977-79 (pp. 113-126). London: English Heritage.

Tomlin, R. S. O. (1998). Roman Manuscripts from Carlisle: the Ink-Written Tablets. Britannia, 29, 31-84.

Tomlin, R. S. O. (2009). Roman Britain in 2008: III. Inscriptions. Britannia, 40, 313-363.

Tomlin, R. S. O. (2010). Roman Britain in 2009: III. Inscriptions. Britannia, 41, 441-469.

Tomlin, R. S. O. (2011). Roman Britain in 2010: III. Inscriptions. Britannia, 42, 439-466.

Tomlin, R. S. O. (2012). Roman Britain in 2011: III. Inscriptions. Britannia, 43, 395-421.

Tomlin, R. S. O. (2013). Roman Britain in 2012: III. Inscriptions. Britannia, 44, 381-396.

Tomlin, R. S. O. (2014). Roman Britain in 2013: III. Inscriptions. Britannia, 45, 431-462.

Tomlin, R. S. O. (2015). Roman Britain in 2014: III. Inscriptions. Britannia, 46, 383-420.

Tomlin, R. S. O. (2016). Roman London's First Voices. Writing Tablets from the Bloomberg excavation, 2010-2014. London: MOLA.

Francesca Cotugno PhD / Francesca.cotugno@nottingham.ac.uk

University of Nottingham

Centre for the Study of Ancient Documents (CSAD)

University of Oxford, Faculty of Classics

66 St Giles', Oxford OX1 3LU, United Kingdom 
